\title{
交通騒音のうるささに及ぼす振動の影響の有無 EXISTENCE OF THE EFFECT OF VIBRATION ON TRAFFIC NOISE ANNOYANCE
}

\author{
佐藤哲身* \\ Tetsumi SATO
}

\begin{abstract}
The purpose of this study is to evaluate the contribution of the traffic vibrations to the noise annoyance through two surveys.

The first survey was carried out in terms of road traffic noise and vibration in Sapporo City. The survey comprised attitude interviews and the physical measurements outdoors. It was found that people responded with greater annoyance to the same traffic noises in the areas where traffic vibrations were severer.

The second survey was carried out in terms of railway noise and vibration in the same manner as the case of road traffic. Almost the same results were obtained.
\end{abstract}

Keywords : traffic noise, traffic vibration, annoyance 交通騒音，交通振動，うるささ

\section{1..はじめに}

等価騒音レベル $\left(L_{e q}\right)$ を騒音評価の基礎尺度として 用いることの有効性が広く認められつつある。しかし， 現実の場での騒音の評価を考えた場合, 音のエネルギー 以外の要团を無視できないことは明らかである。例えば, アンケート調查を実施して，ある音のうるささについて 質問した場合，明らかに同程度の音にさらされていると 思われる住民の回答に，大きなばらつきが認められるこ とが多い。これを個人差としてとらえる立場もあるが， 音源に伴う様々な情報や音以外の刺激によって，住民の 回答が影響を受ける可能性のあることは想像に難くな い。このように，個人の心理的要因はもとより，音以外 の外的刺激が，騷音に対する住民反応に影響を及ぼして いる可能性は十分に考えられる。なかでも，振動は，同 一発生源からの物理的刺激という意味で注目すべき要因 と言えよう。しかし，これまでに公表された研究は騒音 と振動を独立に扱ったものがほとんどであり，相互影響 を扱った研究は少ない。道路や鉄道といった陸上交通に ついてみると, 騒音と振動は, 共に心理的不快感をもた らす代表的な刺激であり，特に日常生活の場において， これらの相互影響を検討することは意義深いものと考え る。Guignard"は，種々の側面から，この分野の既往の 研究をまとめているが，ここでは，その後に公表された 幾つかの研究を概観してみたい。
西宮 ${ }^{2}$ は，自動車，航空機，新幹線，工場等の騒音・ 振動に関する数多くの社会調査にたずさわった経験か ら, 騒音と振動に対する住民の態度反忘の相違について 次のとおり分析している。すなわち，「騒音に対する態 度反応については騒音暴露量などの物理的要因が最も大 きい寄与度をもっているのに対し，振動に対する態度反 応は物理的要因と一義的に対応せず，同時に存在する騒 音のうるささなどによってママスクされている。よ述べ ている。また, 具体的な影響に関する項目中, “house vibrate”に対して, 騒音レベルが大きく寄与している としている。これは騒音レベルと振動レベルの相関が高 いことによるとも考えられるが, 騒音と振動に対する態 度反応が，何らかの形で相互に影響しあっていることを 示唆するものである。豊田 ${ }^{31}$ は，在来鉄道騒音・振動に 関する物理量の実測と沿線住民へのアンケートを広範な 地域で実施し，数量化理論に基づいて態度反応の尺度化 を試みている。騒音については騒音レベルの寄与率が大 きいことから尺度化が可能であるが，振動については尺 度化可能な水準に達することができなかったとしてお り，振動に対する住民反応の複雑さを強調している。 Fields"1 は，鉄道騒音に関する大規模な調査の中で，騒 音以外のいろいろな刺激（振動，ちり，臭いなど）に関 してアンケートを行い，騒音以外では，振動がアノイア ンスに最も大きな影響を及ぼすことを示した。さらに騒 
音のアノイアンスに影響を及ぼす要因と同様の要因が, 振動のアノイアンスに影響を及ぼしているとしている。

以上は，騒音と振動に関する社会調查から, 態度構造 の相違について考察したものである。次に，騒音と振動 の相互影響を直接扱ったものについて述べる。これらは 大きく，1）感覚領域での相互影響と，2）作業に対する 影響の $2 つ に$ 分類されるが，ここでは，本論と関連の強 い前者について紹介する。

Fleming et al. ${ }^{5)} は$ ，恒常法を用いて騒音と全身振動 の主観的等価値を求める実験を行い, 騒音と振動によっ て生ずる相対的な不快感 (displeasure) について検討 を行った。得られた結果は大きな個人差を伴っているも のの, この研究は, 不快感という一つの尺度上で騒音と 振動の直接比較が可能であることを示したものと言え る。徳山 ${ }^{6}$ は, 騷音と振動に対する感覚反応の相互影響 について実験を行い，その結果，振動は音の「大きさ」 には影響を及ぼさないが，「不快感」には相互影響の可 能性があるとしている。吉川ら”は，人間が純音を聞い ている時, その純音と周波数の等しい正弦振動を人体に 与えると, 純音のラウドネスが増大するという知見をも とに，低域での聴覚感度の低下によるラウドネス減少を 補正するためにはよ゙の程度の振動を人体に与えたら良い かを実験によって検討した。ラウドネス変化の要因を 3 種類あげ，各々を検討した結果，ラウドネスの増大に最 も大きく寄与する要因は振動感覚であり，その他の要因 の影響は小さいという結論を得ている。すなわち，聴感 と振動感覚の相互影響の存在が確認されている。

以上，感覚領域における騒音と振動の相互影響につい ていくつかの研究成果を見てきた。結論に相違はあるに せよ，いずれの結果も騒音と振動の間に何らかの相互影 響を見いだしているものといえよう。

筆者はこの問題に着目し，札幌市において，道路およ び鉄道周辺の騒音・振動に関する 2 シリーズの社会調査 を実施し，騒音のうるささに及ぼす振動の影響について 検討を行った。本論においては, 振動レベルの大きな地 域と小さな地域とで，騒音のうるささに関する住民反応 に相違が認められるか否かを検討する。

\section{2. 道路交通騒音・振動に関する調査 ${ }^{10)}$}

本調査に先立ち, 札幌市内の広範な地区を対象として， 視察と簡単な実測による予備調查を実施した。その目的 は，1）騒音レベルと振動レベルの関係ができるだけ巽 なる地区を見つけること，2）ある程度まとまった軒数 の住宅が存在する地区を見つけることの 2 点である。そ の結果選定された 13 の調查対象地区は, 道路からの距 離ができるだけ等しくなるように2〜3のブロックに区 分された。ブロックの数は総計 37 となり，各々 10 軒程 度の住戸を含んでいる。一例を図一1に示す。アンケー

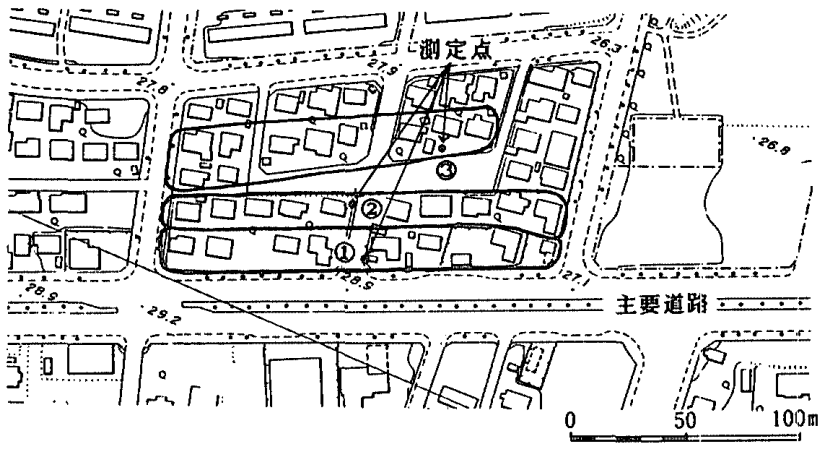

图一1 地区内住戸の分類と測定点の例 （道路交通騒音・振動の場合）

表一1＼cjkstart調查票の概要（道路交通騒音・振動の場合）

\begin{tabular}{|c|c|}
\hline 分顆 & 主な内容 \\
\hline 住民の属性(Face) & 年齢、性別、世带主の瞕業、家族数、家の棈造 \\
\hline 地域環境 & 交通の便、買い物の便、公共施設、公害意雍 \\
\hline 䮜音全般 & 気になる音の種類、車の理類、近瞵馶音 \\
\hline 道路交通騒音 & 具体的影珵、うるささ(き)、季節、時問 \\
\hline 振動全般 & 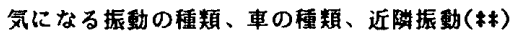 \\
\hline 道路交通振動 & 具体的影瑤、気になる程度 (キ)、季節、時間 \\
\hline 騒音・振動全股 & 気にしている家族、対処の仕方、的合被害意㖪 \\
\hline （再ひ）地域懪境 & 移転の意思と原因、日常生活上の不满 \\
\hline 部亘虽锼察 & 周迅状况、回答者の性格、建物の程䫓 \\
\hline
\end{tabular}

～主筧問：道路交通騒音のうるささ、道路交通振動の気になる程 度については 5 段階のカテコリー評定(非常にーかなりーやや 一あまり一全く)

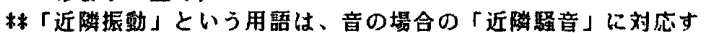
るものとして用いており、列えば住宅用設碏機器に伴う层動な どを想定している。

卜調查の実施時期は昭和 59 年 9〜10月, 騒音レベルと 振動レベルの実測はアンケート調査終了後の 10 11月 に行った。アンケート調查は，これに先駆けて，調査㳔 象の住戸 354 戸に対して調查予定日時を記入した依頼 状を配布し，本調査では訪問面接法を採用した。調查㳔 象は原則として主婦としたが，止むを得ない場合は，普 段家に居て一日の様子が伺える機会の多い人に回答を求 めた。また, 住戸構造はすべて木造一戸建に限定した。 最終的な有効回答数は 219 件である。調査票は「生活澴

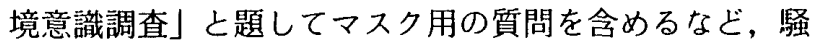
音, 振動に関する調查だという先入観を与えないように 配慮した。調查票の概要は表一1のとおりで, 32 の質問 項目亡 9 の調查員観察項目から成っている。なお, 主質 問の「道路交通騒音のうるささ」, 「道路交通振動の気に なる程度」は表一1のとおり，5段階のカテゴリ一評定 とした。一方, 騷音レベル・振動レベルの测定について は, 各地点の屋外に代表的かつ測定器設置可能な測定点 を一箇所設置し，4時間书き $(7,11,15,19,23 ， 3$ 時台) に 10 分間ずつ計 6 回, 騒音計 (RION NA-20), 振動 レベル計 (RION VM-14 B) とレベルレコーダ (RION LR-04) で記録した。騒音レベルは周波数補正回路 $\mathrm{A}$ 
特性, 動特性 fast, 振動レベルは鉛直方向のみとし, 振 動感覚補正回路を通して記録した。振動レベルの測定を 鉛直方向のみに限定したのは，昭和 58 年度に行った調 查9 により，鉛直方向と水平方向のレベルの相関が高い こと，および，鉛直方向の指示値が最も大きな值を示し たことからこれのみで全体を代表させて問題ないと判 断したためである。このようにして記録した 10 分間ず つ 6 回, 計 60 分の騒音レベル, 振動レベルの波形が 1 日のレベル変動を表していると仮定し， 5 秒ごと，計 720 個のレベルを読み取って, 騒音・振動の各種評価尺 度 $\left(L_{x}, L_{\text {eq(24) }}, L_{d n}\right.$ 等) の值を計算した。以下，混同を 避けるために, 振動レベルについては $V L_{x}$ 等, 記号の 頭に $V$ を付けて表すことにする。

さて, 社会調査を行う際には, 回答者にバイアスのか からないように十分注意する必要がある。この調査は騒 音のうるささに及ぼす振動の影響を検討することが主目 的であるため，筆者は図一 2 に示す手順で調查を進める ことにより, バイアスの除去を試みている。すなわち， 1つは，通常行うように，アンケート調査終了後に物理 的測定を行うこと，さらに「騷音」に関する質問項目の 後に「振動」に関する項目を置くことである。これによ り，少なくとも振動に関する質問が騒音に関する回答に 影響を与えることはないと言える。

図一3は，13 地区の各ブロックにおける騒音レベル $\left(L_{e q(24)}\right)$ と振動レベル $\left(V L_{10}\right)$ の関係である。双方の

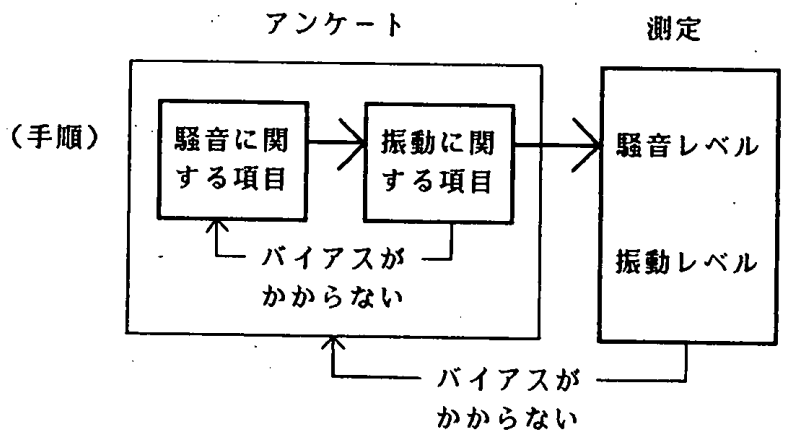

图一2 アンケートと物理的測定の手順

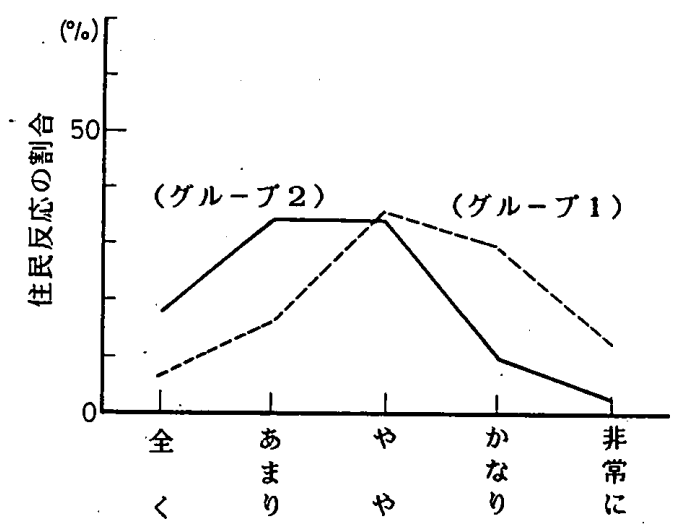

騒音のうるささ
評価量に $L_{e q(21)}$ と $V L_{10}$ を採用したのは, 現在, わが国 で用いられている変動騒音・変動振動の評価量の代表的 なものであることによる。図から明らかなように，地区 番号 $(4,5,6,9,10,11,12,13)$ のグループは他の地 区に比ベて振動レベルが大きくなっている。札幌という 地域性もあって, いずれの地区も振動レベルは大きいと

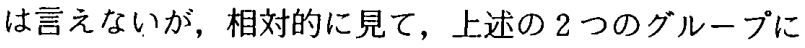
分類できると考えられる。そこで地区番号 $(4,5,6,9$, $10,11,12,13)$ の地区をグループ1, 他の地区をグルー プ 2 と呼ぶことにする。なお，一部の地区の $V L_{10}$ がか なり小さな值を示しているが，これらの測定值は機器の 内部ノイズの影響を受けない範囲のものであることを確 認している。このように各地区においては騒音レベルと 振動レベルに相関が認められるものの, 全体として見る と, 騒音レベルがほぼ同じ地区でも振動レベルに大きな 相違のある様子が伺える。図一4は，それぞれ騷音と振

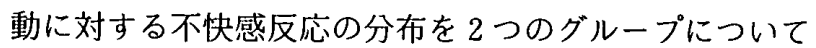
比較したものである。振動はもちろん, 騒音についても 両者に相違が認められる。すなわち, 振動については全

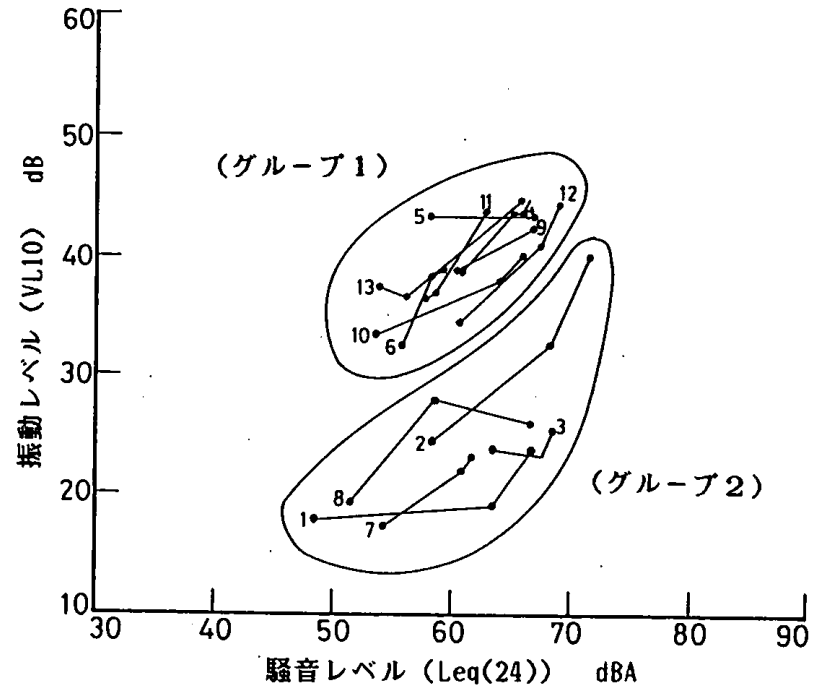

図一3 地区別道路交通騒音レベル $\left(L_{\text {eq120 }}\right)$ と振動レベル $\left(V L_{10}\right)$ の関係

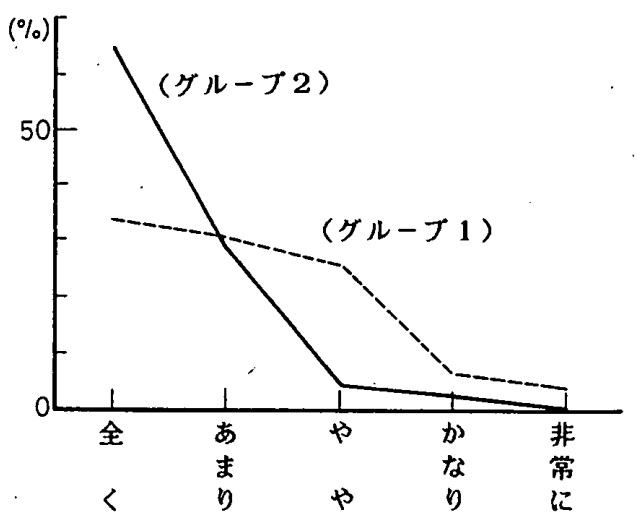

振動の気になる程度

図一4 道路交通騷音と振動に対する住民反応の分布 
表一2 道路交通騒音のうるささに関するコルモゴロフ・スミルノフ検定の結果 ( $\mathrm{S} 1(\mathrm{X})$ と $\mathrm{S} 2(\mathrm{X})$ は グループ別うるささ正反応の相対累積度数を表す)

\begin{tabular}{ccccccccccc}
\hline Leq $(24)$ & $52-54$ & $54-56$ & $56-58$ & $58-60$ & $60-62$ & $62-64$ & $64-66$ & $66-68$ & $68-70$ & $70-72$ \\
\hline S1 $(x)$ & 0.052 & 0.082 & 0.144 & 0.361 & 0.474 & 0.588 & 0.845 & 0.969 & 1.000 & 1.000 \\
$S 2(x)$ & 0.044 & 0.044 & 0.044 & 0.156 & 0.244 & 0.289 & 0.289 & 0.578 & 0.867 & 1.000 \\
$\mid S 1(x)-S 2(x)$ & 0.008 & 0.038 & 0.100 & 0.205 & 0.230 & 0.299 & 0.556 & 0.391 & 0.133 & 0.000
\end{tabular}

1. two tailed test: $D .01=1.63 \sqrt{(97+45) /(97 \times 45)}=0.294$

$D=\max .|S 1(X)-S 2(X)|=0.556, \quad D>D .01, \quad$ significance of $1 \%$ level

2. one tailed test: $\chi^{2}=4 \times(0.556)^{2} \times(97 \times 45) /(97+45)=38.0, \quad \chi^{2} .0,(2)=9.21$ $x^{2}>\chi_{.01}^{2}(2)$, significance of $1 \%$ leve 1

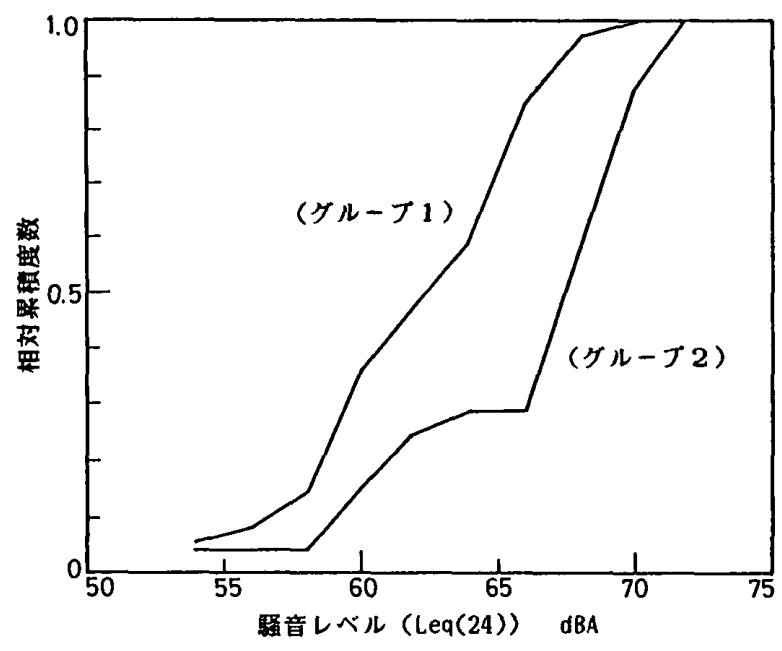

図一5グループ別「道路交通騒音のうるささ」正反応の分布

体的に「気にならない」と言う回答者が多いが, 中でも グループ 2 はその比率が大きい。また騒音の「うるささ」 は，いずれも「ややうるさい」付近が最大比率を占めて いるが,グループ 2 はうるささの程度が小さな方向に偏 り,グループ1はよりうるさい方向へと偏りが見られる。 次に，両グループについて，そのうるささ反応と騒音 レベルの関係を直接比較してみたい。うるささの各カテ ゴリーに回答した人数に大きな偏りがあるため,ここで は，騒音のうるささに対する正反対（やや，かなり，非 常に）を一括して扱い，その数の騒音レベルに関する累 積度数曲線を描いて分布状態を比較することにした。図

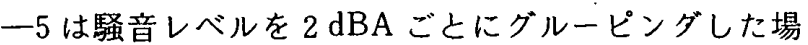
合の比較である。騒音レベルのレンジは両グループとも ほぼ同じであるが，例えば正反心に該当する回答者のう ち半数が存在するレベルはグループ 1 で約 $62 \mathrm{dBA}, ク ゙$ ループ 2 で約 $68 \mathrm{dBA}$ と $6 \mathrm{dBA}$ 程度の相違として表れ

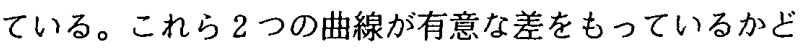
うかを検定する目的で，コルモゴロフ・スミルノフの検 定 $^{8)}$ を行った。この検定法は, いわゆるノンパラメトリッ ク検定法の一種で, 変量が順序尺度のときに用いられる。 この方法を用いたのは，1）2つのグループの母集団の 分布が正規分布であるという仮定がたてにくく分布の型 が明確でないこと，2）騒音レベルの単位であるデシベ
ル尺度が本来順序尺度であることの $2 つ$ つ理由による。 検定の計算および結果を表一 2 に示す。両側検定の結唬 $1 \%$ 水準で有意差が認められ, 両者は異なる姆集団か らのサンプルであると言える。さらに，片側検定の結果 からも同様に $1 \%$ 水準で有意差が認められ，グループ 1 の累積度数の增加傾向が, グループ 2 を上回ると結論 できる。

以上により，振動が騒音のうるささに影響を及ぼす可 能性が強いという結論を得た。

\section{3. 鉄道騒音・振動に関する調査 ${ }^{11}$}

前節と同様の目的および方法で, 昭和 62 年 9 月から 11 月にかけて，札幌市内を走る 3 本の鉄道沿線におい て調查を実施した。調查対象地区は 9 地区であり，調查 対象住戸 319 戸から得られた有効回答数は 154 件であ る。対象地区の一例を図一6に示す。騷音レベル・振動 レベルの測定については，各ブロックの屋外に代表的か つ測定器設置可能な測定点を一箇所設置し, 騒音計と振 動レベル計の出力をデータレコーダ (TEAC R-61) に 記録した。これらのデータを持ち帰り，騒音レベルにつ いては周波数補正回路 A 特性および動特性 fast の設定 でまた振動レベル（鉛直方向のみ）については，振動 感覚補正回路を通して,レベルレコーダ (RION LR-04) に波形を記録した。対象地区を通過する列車はすべて旅 客専用であり，貨物列車は含まれていない。また，通過

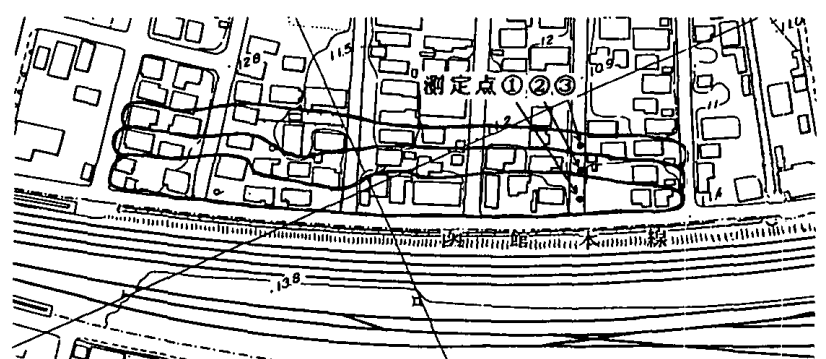
300

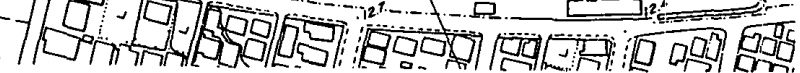
0

図一地区内住戸の分類と測定点の例 (鉄道騒音・振動の場合) 
列車の本数は，地区番号 1 が 113 本，地区番号 2 が 199 本, 地区番号 9 が 66 本, その他の地区が 325 本である。 これらの列車を特急, 急行, 快速, 普通等の種類と車両 編成をもとに数グループに分類し，各グループの代表的 なものについて, 上り列車, 下り列車の通過時の波形を 記録した。この波形から 0.25 秒ごとのレベルをサンプ リングし，図一7に示す方法で 1 列車あたりの Total Energy Level $\left(L_{e n}\right)$ を計算した。さらに,これを全列 車についてエネルギー加算して，1日あだりの総暴露エ ネルギーレベルを求めた。以下，混同を避けるために，

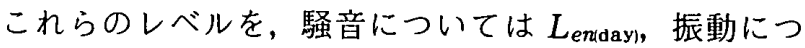
いては $V L_{\text {enday) }}$ と表記することにする。

図一8は，9 地区の各地点における，騒音と振動の 1 日の総暴露エネルギーレベル $\left(L_{\text {enday }), V} V L_{\text {en(day) }}\right)$ の関 係を表している。図から明らかなように，地区番号（5， 7,9）のグループは他の地区に比べて振動レベルが小さ くなっているのが分かる。そこで，相対的に振動レベル の大きな地区 $(1,2,3,4,6,8)$ をグループ1，小さな 地区 $(5,7,9)$ をグループ 2 と呼ぶことにする。前節の

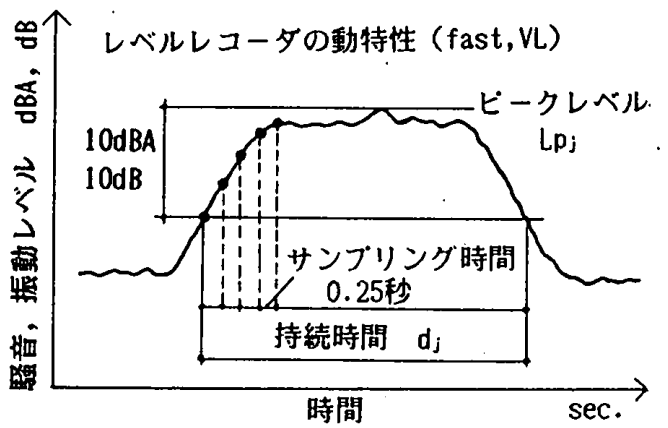

* 1 列車あたりの Total Energy Level Len $_{j}=10 \log 10\left\{\left(1 / n \cdot \sum 10^{L i / 1 \theta}\right) \cdot d_{j}\right\}$ $\mathrm{n}$ ：サンブリング数

*1日あたりの想暴露ネルギーレベル Len(day) $=10 \log 10 \sum^{N} 10^{\operatorname{lonj} 1} 18$ N：1 日の通過列車本数

（尉動についてはVLenと表記する）

図一7 鉄道騒音・振動の時間特性に関する用語の定義

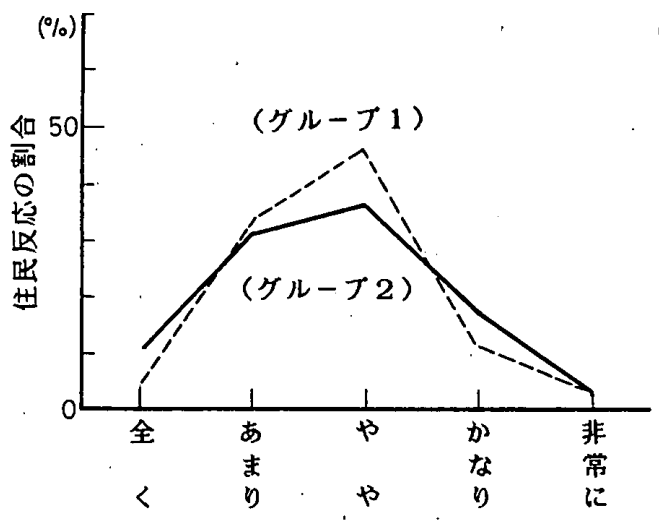

騒音のうるささ
道路交通騷音・振動の場合と同様に，騷音レベルがほぼ 同じ地区でも振動レベルにかなりの相違のある様子が伺 える。図一9は, 騒音と振動に対する不快感反応の分布 を2つのグループについて比較したものである。図に示 すとおり，前節の道路交通騒音・振動の場合に比べて両 グループに明確な傾向の相違は認められない。ただし， 正反応 (やや，かなり，非常に）の割合を比べると，グ ループ1では騒音と振動に対する正反応がそれぞれ $62.5 \%$ と $38.3 \%$ ，グループ 2 では $58.3 \%$ と $36.7 \%$ であり，若干ではあるがグループ1がグループ 2 を上 回っている。ここでは，前節と同様に，騒音のうるささ に関する正反応の累積度数分布を描き，その分布状態に より比較することにする。図一10はその結果である。 騒音レベルのレンジは両グループともほぼ同じである が，正反応に該当する回答者のうち半数が存在するレベ ル ( $\left.L_{\text {enday }}\right)$ はグループ1 で約 $104 \mathrm{dBA}$ ，グループ 2 で 約 $109 \mathrm{dBA}$ と $5 \mathrm{dBA}$ 程度の相違として表れている。こ れら 2 つ曲線に，コルモゴロフ・スミルノフの検定を 適用した結果が表一3であり，5％水準で有意差が認め

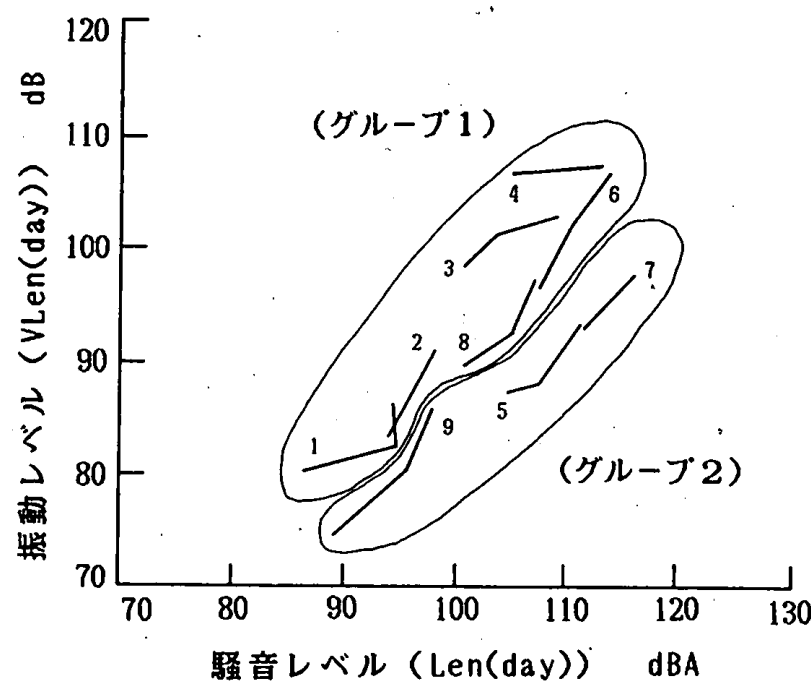

図一8 地区別鉄道騷音レベルと振動レベルの関係 (1日の総暴露エネルギーレベル)

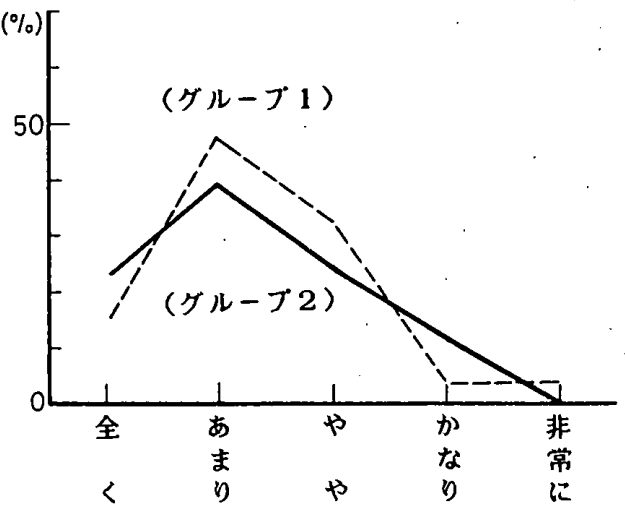

振動の気になる摆度

図一9鉄道騒音と振動に対する住民反応の分布 
表一3 鉄道騒音のうるささに関するコルモゴロフ・スミルノフ検定の結果 (S $1(\mathrm{X})$ と $\mathrm{S} 2(\mathrm{X})$ は グループ別うるささ正反応の相対累積度数を表す)

\begin{tabular}{ccccccccc}
\hline Len(day) & $86-88$ & $88-90$ & $90-92$ & $92-94$ & $94-96$ & $96-98$ & $98-100$ & $100-102$ \\
\hline S1(X) & 0.017 & 0.017 & 0.017 & 0.017 & 0.237 & 0.237 & 0.305 & 0.424 \\
S2(X) & 0.000 & 0.057 & 0.057 & 0.057 & 0.171 & 0.286 & 0.286 & 0.286 \\
$|S 1(x)-S 2(x)|$ & 0.017 & 0.040 & 0.040 & 0.040 & 0.066 & 0.049 & 0.019 & 0.138 \\
\hline Len(day) & $102-104$ & $104-106$ & $106-108$ & $108-110$ & $110-112$ & $112-114$ & $114-116$ & $116-118$ \\
\hline S1(X) & 0.458 & 0.610 & 0.780 & 0.847 & 0.881 & 1.000 & 1.000 & 1.000 \\
S2(X) & 0.286 & 0.371 & 0.514 & 0.514 & 0.857 & 0.857 & 0.857 & 1.000 \\
$|S 1(x)-S 2(x)|$ & 0.172 & 0.239 & 0.266 & 0.333 & 0.024 & 0.143 & 0.143 & 0.000 \\
\hline \hline
\end{tabular}

1. two tailed test: $0.05=1.36 \sqrt{(59+35) /(59 \times 35)}=0.290$

$D=\max .|S 1(X)-S 2(X)|=0.333, \quad D>0.05, \quad$ significance of $5 \%$ leve 1

2. one tailed test: $\chi^{2}=4 \times(0.333)^{2} \times(59 \times 35) /(59+35)=9.744, \quad \chi^{2} .05(2)=5.991$ $\chi^{2}>\chi_{.05}^{2}(2)$, significance of $5 \%$ level

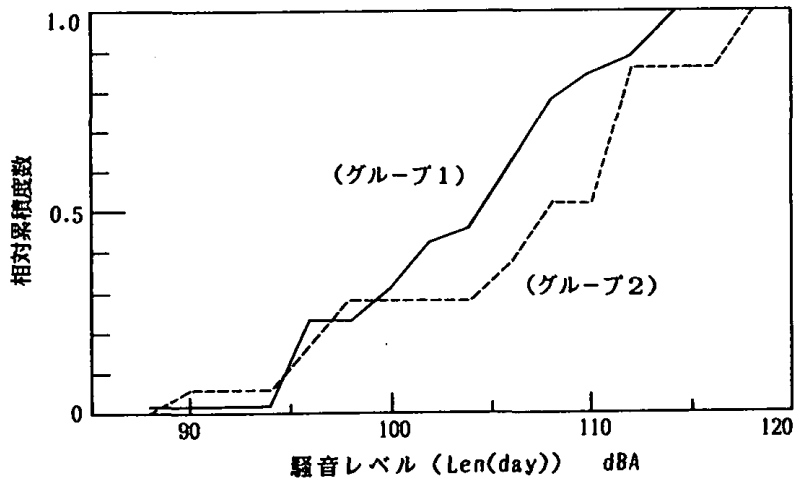

図一10 グループ別「鉄道騒音のうるささ」正反応の分布

られた。すなわち,グループ1の累積度数の増加傾向が, グループ 2 を上回ると結論できる。

以上により，道路交通騒音と同様，鉄道騒音に関して も，振動が騒音のうるささに影響を及ぼす可能性が強い という結論を得た。

\section{4. おわりに}

以上， 2 シリーズの調查を通して，騒音のうるささに 及ぼす振動の影響について検討を行った。評価尺度が異 なるので厳密な意味での比較はできないが, 今回の調查 地区においては，鉄道よりも道路交通の場合の方が，2 つのグループ間の振動レベルの差が大きいと言える（図 -3亡図一8)。また，騒音のうるささに関する正反応の 分布の差も道路交通の場合に顕著であり，統計的な有意 水準も上回っている（図一 4 と図一 9 , および図一 5 と図 $-10)$ 。

以上をまとめると，以下のとおりである。

(1) 道路交通騒音および鉄道騒音のうるささに関する住 民反応は, 同じ発生源からの振動の影響を受けて形成さ れる可能性が強く，振動レベルが大きな場合にうるささ 反応も大きい。

(2) 道路交通騒音に関する調査地区の振動レベルの差は 鉄道の場合よりも大きく，また，うるささ反応の相違も
顕著なことから，一般に，振動レベルの差が大きいほど， うるささ反応の差も大きくなることが予想される。

初めにも述べたように，騒音のうるささに影嵬を及ぼ す要冈は多岐にわたり，住民反応を十分に説明するため には，騒音レベルと振動レベル以外にも，多くの要因が 必要と思われる。しかし，振動という要因に積極的に踷 目した場合，音源の異なる $2 つ$ 調査において同じ結論 が得られたことは，結論の普遍性を裏付けるものと考え ることもできよう。もちろん，ここで得られた知見は今 回実施した調査の範囲に限られるものであり，振動レバ ルが非常に大きい場合については明らかでない。また， 物理量の測定位置, 言いかえれば室内や屋外のに゙の位砠 の騒音や振動を問題にすべきかも大きな課題として残さ

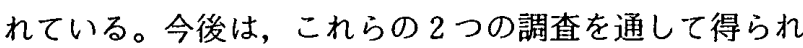
た知見をもとに，より詳紐な調查を行い，交通騒音のう るささに及ぼす振動の影響の定量的予測法の検討を行う 予定である。

おわりに，本論をまとめるにあたり，貴重なご助言衤 頂いた室蘭工業大学・泉 清人教授と, 調查・分析にご 協力頂いた多数の北海学園大学学生諸君に謝意を表す る。

\section{参考文献}

1) Guignard, J.C. : Combined Effects of Noise and Vibration on Man, University of Dayton Technical Report 73-51, pp. 1 12, 1973.

2）西宮 元：騒音・振動に関する社会反応とその特徵につ いて, 日本音響学会誌, Vol. 32, No. 3, pp. 147 155, 1976.

3）豊田栄次：鉄道騒音振動と住民意識，騒音制御，Vol.3, No. 2, pp. 24 27, 1979.

4) Fields, J. M. : Railway Noise and Vibration Annoyance in Residential Areas, J. Sound Vib., Vol.66, No.3, pp. 445 458, 1979.

5) Fleming, D. B. and Griffin, M. J. : A Study of the Subjective Equivalence of Noise and Whole-Body Vibration, J. Sound Vib., Vol. 42, No. 4, pp. 453 461, 1975. 
6）徳山久雄：騷音と振動の複合入力による感覚反応，騒音 制御, Vol..6, No. 3, pp. 43〜 47, 1982.

7）吉川昭吉郎，佐野和久，佐藤達哉：ラウドネスに対する 振動の寄与, 日本音響学会聴覚研究会資料, H-86-42, pp. $1 \sim 8,1986$.

8）肥田野直, 瀬谷正敏, 大川信明：心理教育統計学, 培風館, pp. 89 94, 1961.

9）佐藤哲身：道路交通騒音・振動の不快感の評価に関する 社会調查（1），日本建築学会北海道支部研究報告集（計 画系), No. 57, pp. 105 108, 1984.

10）佐藤哲身：騒音のうるささに及ぼす振動の影響：札㹸市
における交通騒音・振動に関する社会調査, 日本音響学 会騒音研究会資料，N87-01-2，pp. 1 -8，1987.

11）佐藤哲身：騒音のうるささに及ぼす振動の影響 $(2)$ ：札 幌市における鉄道騒音・振動に関する社会調查, 日本音 響学会騒音研究会資料, N89-1-05, pp. 1 6, 1989.

12) Sato, T. : Two Surveys on the Effect of Vibration on Traffic Noise Annoyance, Proceedings of Inter-Noise 90, pp. 1339 1342, 1990.

(1991 年 3 月 7 日原稿受理, 1991 年 7 月 4 日採用决定) 